\title{
Overexpression of c-met Protein in Gastric Cancer and Role of uPAR as a Therapeutic Target
}

Hyun A Oh, M.D., Gu Lee, M.D., Hee Jung Kang, M.D., Yong Gil Kim, M.D., Sung Hwa Bae, M.D., Jae Lyun Lee, M.D., Kyung Hee Lee, M.D., Myung Soo Hyun, M.D. and Dong Suk Kim, M.D.'

Departments of Internal Medicine and ${ }^{1}$ Pathology, Yeungnam University College of Medicine, Daegu, Korea

Purpose: One of the members of the tyrosine kinase receptor family is the protein product of the c-met proto-oncogene, which is the receptor for hepatocyte growth factor (HGF). HGF is known as a potent mitogen and motogen for many kinds of carcinoma cells, and has been found to simulate the growth and progression of gastric cancer cells through HGF-receptors. In addition, the urokinase-type plasminogen activator (UPA) and receptor (UPAR) also play important roles in the invasion and metastasis.

Materials and Methods: The expression of c-met protein was investigated using immunohistochemical staining of 50 paraffin embedded gastric cancers, and by measuring the serum UPAR levels, before and after an operation, in gastric cancer patients using an ELISA assay.

Results: Of the 50 cases, $32(64 \%)$ expressed the c-met protein. The $c-m e t$ protein expression was significantly correlated with the TNM staging $(p<0.05)$, but the other prognostic factors were not significant variables. Accord-

\section{서 론}

위암은 우리나라에서 발생 및 사망빈도가 가장 높은 악성 종양으로, 현재까지 완치를 기대할 수 있는 유일한 치료법 은 외과적 절제술이다. 조기위암 상태에서 수술을 받을 경 우 생존율이 $90 \%$ 이상으로 좋은 결과를 보이지만 우리나라 의 경우 $70 \%$ 이상에서 진행된 상태로 수술을 받기 때문 에 진행위암의 예후를 예측할 수 있는 인자를 밝혀내고 수술 후 치료방침을 결정하는 것이 중요하다고 할 수 있 다(1). 위암의 예후인자는 원격전이, 위벽침윤도, 림프절 전 이, 종양의 분화도, 육안적 분류 등이 있고 그중 병기가 가

Correspondence: Kyung Hee Lee, Department of Internal Medicine, Yeungnam University College of Medicine, Daemyong-dong, Nam-gu, Daegu 705-035, Korea. (Tel) 053-620-3845, (Fax) 053654-8386, (E-mail) 1khee@med.yu.ac.kr

Received October 14, 2002, Accepted November 22, 2002

This study was financially supported by Yeungnam University in the program 2002 ing to a Kaplan-Meier's plot, the one and three year overall survival rates were 94 and $70 \%$ in patients not expressing the c-met protein, and 81 and $33 \%$ in those that did, and the Survival curves revealed a significantly different prognosis $(p=0.04)$. Elevated serum uPAR levels $(\geq 3257.8$ $\mathrm{pg} / \mathrm{ml}$, control mean $\pm 2 \mathrm{SD})$ were observed in $9(34.6 \%)$ of 26 gastric cancer patients, but in none of control subjects. Average serum uPAR levels were $2980.8 \pm 616.2 \mathrm{pg} / \mathrm{ml}$ before the operation and $2404.7 \pm 455.9 \mathrm{pg} / \mathrm{ml}$ after, and decreased significantly after surgical resection $(p<0.05)$. The serum UPAR level correlated significantly with lymph node metastasis and vessel invasion $(p<0.05)$

Conclusion: The expression of $c-m e t$ protein, and the level of UPAR, may be prognostic factors in gastric cancer. (Cancer Research and Treatment 2003;35:9-15)

Key Words: Stomach neoplasm, c-met, Urokinase-type plasminogen activator

장 의의가 있으나 동일한 병기의 환자에 있어서도 재발, 생 존여부가 다양하여 새로운 예후 인자를 찾는 시도가 시행 되었다. 이에 DNA ploidy, 증식활성, 암유전자의 증폭이나 과발현 등의 생물학적 인자들이 대두되었고(2), 최근 분자 생물학의 발달에 힘입어 암의 발생은 축적된 유전자의 변 화의 결과라는 것이 정설로 받아들여짐에 따라 암유전자, 암억제유전자 혹은 성장인자 및 그의 수용체를 암표식자나 예후인자로 이용하려는 연구들이 진행되고 있다. 암유전자 는 Huebner와 Todaro가 처음 기술한 이래 여러 암종에서 발견되고 있으며(3) 특히 위암에서는 c-myc의 증폭 발현이 확인되었고(4,5), 이후 Starzy-Nska 등이 암억제유전자인 $\mathrm{p} 53$ 의 발현은 위암 환자의 불량한 예후와 상관관계가 있 으며, Yokota 등은 암유전자 c-erbB-2의 발현은 암의 분화 정도와 관련이 있고 Steeg 등이 암전이 억제유전자 $\mathrm{nm} 23$ 의 저발현은 위암 환자의 나쁜 예후와 상관관계가 있다고 하였다(1).

최근에는 악성정도를 반영하는 생물학적 지표로서 성장 인자와 그들의 수용체에 대한 연구가 진행 중이고 이 중 
위암에서는 receptor tyrosine kinase의 변화가 중요한 역할을 수행한다고 알려진 이후 tyrosine kinase receptor family의 하 나인 c-met에 대한 연구가 활발하다. C-met의 산물은 $190 \mathrm{kD}$ 의 transmembrane tyrosine kinase로 간세포 성장인자(hepatocyte growth factor)/scatter factor ( $\mathrm{HGF} / \mathrm{SF})$ 의 수용체로 작용 하며(6), HGF/SF는 c-met을 표현하는 목표장기에서 세포의 증식, 이동, 침습에 관여한다. 즉, $\mathrm{HGF} / \mathrm{SF}-\mathrm{Met}$ 신호체계는 발생시기 동안 조직재생, 상처치유, 신생혈관형성 등에 관 여하는 등 정상적인 생물학적 과정에도 중요한 역할을 수 행하지만(7) 원발병소의 진행과 이차적인 전이에도 핵심적 인 역할을 담당한다(8). C-met은 위암, 대장암, 간암 등에서 과발현됨이 보고되었고(9), c-met 종양단백이 높게 측정될 경우 간암에서 나쁜 예후를 시사하며(10), 위암에서 과별현 시 암의 침윤 및 전이와 관련이 있다고 보고되고 있다(11).

Keizo 등은 위암에서 c-met뿐만 아니라 암의 침습과 관련 이 있는 것으로 알려진 autocrine motility factor receptor (AMFR), urokinase type plasminogen activator receptor (uPAR) 등을 면역조직화학염색을 시행하여 그 발현을 비교하였는 데, 2 개 이상 발현되는 군에서 특히 복강내 전이, 림프절 전 이가 많았으며 생존율이 낮아진다고 하였다(11). 특히 암의 침윤과 전이에 세포의 침습이란 과정이 반드시 필요하며 여기에 단백분해효소가 관여한다고 알려진 후 serine 단백 분해효소인 urokinase-type plasmino-Gen activator (uPA)와 그 수용체인 uPAR의 중요성이 대두되고 있으며, HGF/SF-Met 신호체계가 활성화되어 세포표면에 uPA-uPAR계가 발현되 기 때문에(12) c-met과 uPAR의 관련성에 관한 많은 연구가 진행 중이다.

이에 본 연구에서는 위암으로 진단되어 수술 받은 환자의
파라핀 포매조직에서 면역조직화학염색법을 이용하여 c-met 종양단백의 발현 정도를 알아보고 예후와의 연관성 을 비교 분석하고, 위암 환자의 혈청에서 효소면역분석법 을 이용하여 수술 전후 uPAR농도를 측정하여 혈청 내 $\mathrm{uPAR}$ 농도의 의의를 살펴보고자 한다.

\section{대상 및 방법}

\section{1) 연구 대상}

1998년 1월부터 1999년 12월까지 영남대학교 의과대학 부속병원에서 위암으로 진단되어 수술받은 환자 중 파라핀 포매조직의 보관 상태가 양호하고 임상 기록의 검토가 가 능한 50예를 대상으로 면역조직화학염색을 시행하여 c-met 종양단백의 발현여부를 조사하였다. 연령분포는 22 세에서 77세까지고 평균연령은 57세였으며 남자가 33명 여자가 17 명이었다. 31 명은 위아전절제술을 시행하였고 19 명은 위전 절제술을 시행하였으며 American Joint Committee on Cancer (AJCC, 1997)의 규정에 따라 병기를 분류하였을 때 I기가 3 명, II기가 5명, III기가 19명, IV기가 23명이었다.

혈청 UPAR치를 보기위해 2001년 5월부터 7월까지 위암 으로 확진된 환자 26명을 대상으로 하여 진단과 동시에 정 맥혈을 채취하고 수술을 시행한 후 술 후 7일째 다시 정맥 혈을 채취하여 술 전과 술 후에 효소면역분석법을 이용하 여 혈청 $\mathrm{uPAR}$ 를 측정하였다. 26 명의 환자 중 남자가 16 명 이고 여자가 10 명이었고 연령분포는 31 세에서 77 세로 평균 연령은 55세였다. EGCA가 14명, I기가 2명, II기가 4명, III 기가 5 명, IV기가 1 명이었다. 대조군은 종합건강검진센터 를 방문한 건강인 20명을 대상으로 하였고 이 중 남자가 13

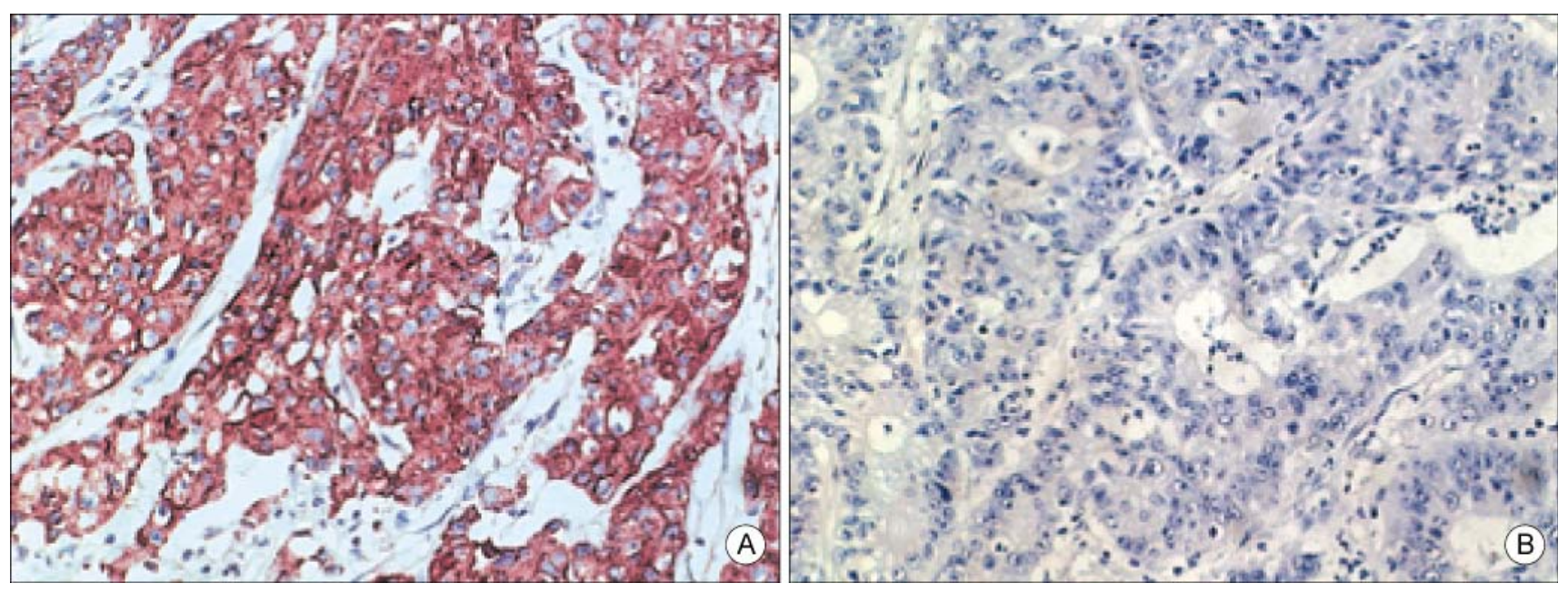

Fig. 1. Immunohistochemical stain for c-met. (A) c-met positive for gastric cancer tissue, (B) c-met negative for gastric cancer tissue (Avidin-biotin complex method, $\times 100$ ). 
Hyun A Oh, et al : c-met and UPAR in Gastric Cancer 11

명, 여자가 7명이었으며, 연령분포는 36세에서 69세까지로 평균연령은 48 세였다. 이들도 정맥혈을 채취하여 효소면역 분석법을 이용하여 혈청 $\mathrm{uPAR}$ 을 측정하였다.

\section{2) 조직에서 c-met 발현}

(1) 면역조직화학염색법: 수술 후 얻은 조직을 $10 \%$ 중성 완충 포르말린 용액에 고정하고 파라핀에 포매된 $4 \mu \mathrm{m}$ 두 께의 종양조직 절편에 파라핀을 제거하기 위해 xylene을 5 분간 4회 작용시킨 후 $95 \%$ 알코올로 4회 탈수하였다. 내인 성 peroxidase반응을 차단하기 위해 methanol과 $3 \%$ 과산화 수소수에 10 분간 처리한 후 조직항원과 항체 간의 비특이적 결합을 억제하기 위해 blocking agent로 10 분간 처리하였다. $1: 50$ 으로 희석한 일차항체로 90 분 동안 반응시킨 후 완충 액(Tris buffered saline)으로 3회 세척한 뒤 이차항체를 15 분 간 반응시킨 후 완충액으로 3회 세척하였다. Avidin-HRP (horse-radish peroxidase)에 15분간 반응시킨 후 AEC (3-amino-9-ethylcarbazole)로 발색을 시키고 Mayer's hematoxylin으 로 대조염색을 시행한 다음 봉입하여 광학현미경으로 관찰 하였다.

(2) 염색 결과의 판정: 광학 현미경하에서 염색강도와는 상관없이 암세포의 $50 \%$ 이상에서 세포막 및 세포질이 진한 적갈색으로 염색된 경우 양성으로 판정하였다(Fig. 1).

\section{3) 혈청 UPAR 효소면역분석법}

혈청내 uPAR 검사는 Quantikine human uPAR kit을 사용 하여 colorimetric sandwitch ELISA로 검사하였다. 환자군 및 대조군의 혈청을 희석액으로 적어도 5 배 이상 희석한 뒤 $\mathrm{uPAR}$ 와 반응하는 murine monoclonal antibody가 coating된 microplate well에 넣고 실온에서 2 시간 동안 반응시킨 다음 완충액으로 4회 씻어내고 200l의 horseradish peroxidase

Table 1. Relationship between c-met expression in tumor tissue and clinicopathologic features in patients with stomach cancer ( $\mathrm{n}=50$ )

\begin{tabular}{|c|c|c|c|c|c|c|c|c|c|}
\hline \multirow[b]{2}{*}{$\begin{array}{l}\text { Clinicopathologic } \\
\text { features }\end{array}$} & \multirow{2}{*}{ No } & \multicolumn{2}{|c|}{ Expression of c-met } & \multirow[b]{2}{*}{ p-value* } & \multirow[b]{2}{*}{$\begin{array}{l}\text { Clinicopathologic } \\
\text { features }\end{array}$} & \multirow{2}{*}{ No } & \multicolumn{2}{|c|}{ Expression of c-met } & \multirow[b]{2}{*}{ p-value } \\
\hline & & $\begin{array}{l}\text { Positive } \\
\text { rate }(\%)\end{array}$ & $\begin{array}{l}\text { Negative } \\
\text { rate }(\%)\end{array}$ & & & & $\begin{array}{l}\text { Positive } \\
\text { rate }(\%)\end{array}$ & $\begin{array}{l}\text { Negative } \\
\text { rate }(\%)\end{array}$ & \\
\hline All patients & 50 & $32(64 \%)$ & $18(36 \%)$ & & Serosa invasion & & & & 0.700 \\
\hline Age & & & & 0.527 & Negative & 17 & $12(70.6 \%)$ & $5(29.4 \%)$ & \\
\hline$<60$ & 29 & $17(58.6 \%)$ & $12(41.4 \%)$ & & Positive & 33 & $20(60.67 \%)$ & $13(39.4 \%)$ & \\
\hline$>60$ & 21 & $15(71.4 \%)$ & $6(28.6 \%)$ & & $\mathrm{L} / \mathrm{N}$ metastasis & & & & 0.730 \\
\hline Sex & & & & 0.813 & Negative & 10 & $7(70 \%)$ & $3(30 \%)$ & \\
\hline Male & 33 & $22(66.7 \%)$ & $11(33.3 \%)$ & & Positive & 40 & $25(62.5 \%)$ & $15(37.5 \%)$ & \\
\hline Female & 17 & $10(58.8 \%)$ & $7(41.2 \%)$ & & Vascular invasion & & & & 1.000 \\
\hline Tumor size & & & & 0.211 & Negative & 17 & $11(64.7 \%)$ & $6(35.3 \%)$ & \\
\hline$<5 \mathrm{~cm}$ & 14 & $11(78.6 \%)$ & $3(21.4 \%)$ & & Positive & 33 & $21(63.6 \%)$ & $12(36.4 \%)$ & \\
\hline$>5 \mathrm{~cm}$ & 36 & $21(58.3 \%)$ & $15(41.7 \%)$ & & Lymphatic vessel & & & & 0.479 \\
\hline Histologic type & & & & 0.642 & invasion & & & & \\
\hline Differentiated & 45 & $28(62.2 \%)$ & $17(37.8 \%)$ & & Negative & 35 & $24(68.6 \%)$ & $11(31.4 \%)$ & \\
\hline Undifferentiated & 5 & $4(75 \%)$ & $1(25 \%)$ & & Positive & 15 & $8(53.3 \%)$ & $7(46.7 \%)$ & \\
\hline Macroscopic type & & & & 0.523 & Neural invasion & & & & 0.612 \\
\hline Bormann 1,2 & 15 & $11(73.3 \%)$ & $4(26.7 \%)$ & & Negative & 24 & $14(58.3 \%)$ & $10(41.7 \%)$ & \\
\hline Bormann 3,4 & 35 & $21(603 \%)$ & $14(407 \%)$ & & Positive & 26 & $18(69.2 \%)$ & $8(30.8 \%)$ & \\
\hline Lauren & & & & 0.405 & Omentum invasion & & & & 0.723 \\
\hline Intestinal & 9 & $7(77.8 \%)$ & $2(22.2 \%)$ & & Negative & 39 & $24(61.5 \%)$ & $15(38.5 \%)$ & \\
\hline Diffuse & 30 & $17(56.7 \%)$ & $13(43.3 \%)$ & & Positive & 11 & $8(72.7 \%)$ & $3(27.3 \%)$ & \\
\hline Intestinal \& diffuse & 11 & $8(72.7 \%)$ & $3(27.3 \%)$ & & Stage & & & & 0.05 \\
\hline Ming & & & & 0.410 & Stage Ib & 3 & $1(33.3 \%)$ & $2(66.7 \%)$ & \\
\hline Expanding & 3 & $1(33.3 \%)$ & $2(66.7 \%)$ & & Stage II & 5 & $1(20 \%)$ & $4(80 \%)$ & \\
\hline Infiltrative & 42 & $27(64.38 \%)$ & $15(35.7 \%)$ & & Stage IIIa & 13 & $7(53.8 \%)$ & $6(46.2 \%)$ & \\
\hline Expanding & 5 & $4(80 \%)$ & $1(20 \%)$ & & Stage IIIb & 6 & $4(66.7 \%)$ & $2(33.3 \%)$ & \\
\hline$\&$ infiltrative & & & & & Stage IV & 23 & $19(82.6 \%)$ & $4(17.4 \%)$ & \\
\hline
\end{tabular}

*calculated by the chi-square test 


\section{Cancer Research and Treatment 2003;35(1)}

conjugate를 각 well에 분주한 후 실온에서 2시간 반응시킨 후 다시 4회 씻어내었다. 200ㅆㅇㅢ tetramethylbenzidine- $\mathrm{H}_{2} \mathrm{O}_{2}$ 기질용액을 넣고 실온에서 30 분간 암실에서 반응시킨 후 $2 \mathrm{~N}$ sulfuric acid stop solution 50l을 넣어 반응을 정지시킨 다음 $450 \mathrm{~nm}$ 파장의 분광계에서 흡광도를 측정하였다.

\section{4) 통계처리}

c-met 종양단백의 발현에 따른 생존율의 비교는 KaplanMeier 방식으로 비교하였으며 생존기간의 유의도 비교는 $\log$-rank 검정법을 이용하였고, 환자군과 대조군의 uPAR 측정치를 구하여 평균표준편차로 나타내었으며 각각의 평균치는 T-test로 검정하였다. 임상병리학적 소견과의 관 계분석은 chi-square방법 혹은 Fisher's exact 방법을 이용하 였고, 모든 통계는 $\mathrm{p}$ 값이 0.05 이하인 경우를 유의하다고 하였다.

\section{결 과}

\section{1) 조직에서 c-met 발현}

총 50명의 환자에서 면역조직화학염색을 시행하여 c-met 종양단백의 발현여부를 관찰하였다. 전체 50예 중 32예 $(64 \%)$ 에서 양성으로 발현되었고, 18 예(36\%)에서는 발현되 지 않았다. C-met 종양단백의 발현과 임상병리학적 소견들 과의 연관성을 보면 Stage Ib $33.3 \%$, II $20 \%$, IIIa $53.8 \%$, IIIb $66.7 \%, \mathrm{IV} 82.6 \%$ 로 병기가 진행될수록 c-met 종양단백의 발 현이 증가됨을 볼 수 있었고 통계학적으로 유의성이 있었 다(p=0.05). 그 외에 성별, 연령, 암의 크기 및 위치, 조직학

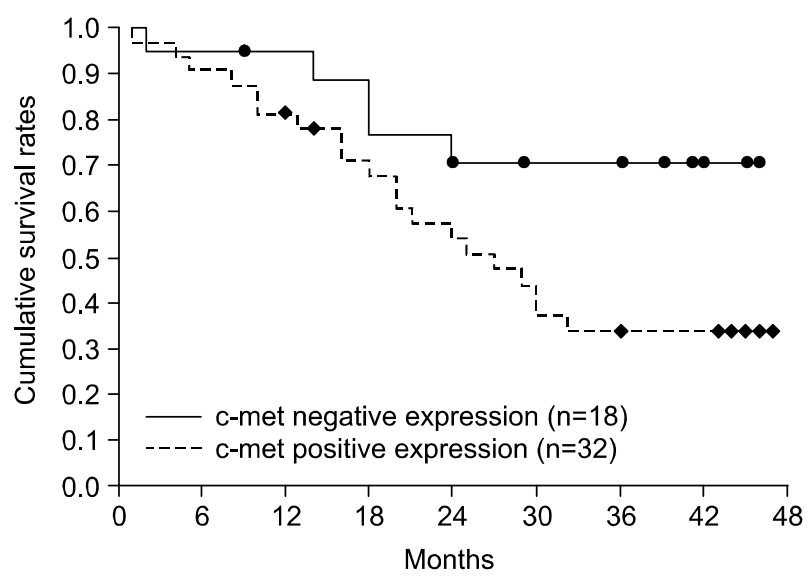

Fig. 2. Cumulative survival curves according to c-met protein expression in all cases $(n=50)$. The survival rates between c-met positive expression group and c-met negative expression group were significantly different $(\mathrm{p}=0.04)$, tested with the log rank analysis.
적 아형, 육안적 혹은 조직학적 소견, 임파절 전이, 암의 침 윤도와는 통계학적으로 유의성이 없었다 $(\mathrm{p}>0.05)($ Table 1). 대상환자 전체를 c-met 양성 발현군(32예)과 음성 발현군 (18예)으로 나누어서 생존율을 비교하여 보았을 때 양성 발 현군의 평균 생존기간은 $28 \pm 3$ 개월이고, 음성 발현군은 37 \pm 3 개월이었다. 양성 발현군의 경우 1 년 생존율은 $81 \%, 2$ 년 생존율은 $54 \%, 3$ 년 생존율은 $33 \%$ 이었고 음성 발현군의 경 우 1년 생존율은 94\%, 2년 생존율은 70\%, 3년 생존율은 $70 \%$ 로 양성 발현군이 음성 발현군에 비해 생존율이 낮았으며 통 계학적으로 유의한 차이를 볼 수 있었다(p=0.04)(Fig. 2).

\section{2) 혈청 UPAR}

환자군 및 대조군의 혈청 uPAR의 농도는 ELISA방법으로 측정하였고 단위는 $\mathrm{pg} / \mathrm{ml}$ 로 표시하였다. 대조군 20 명의 평 균 $\mathrm{uPAR}$ 농도는 $2525.4 \pm 366.2$ (평균 \pm 표준편차) $\mathrm{pg} / \mathrm{ml}$ 이었 고 범위는 $2,064 \mathrm{pg} / \mathrm{ml}$ 에서 $3089.7 \mathrm{pg} / \mathrm{ml}$ 으로 cut-off level은 평균+(2×표준편차)로 하여 $3257.8 \mathrm{pg} / \mathrm{ml}$ 이상을 양성으로 판정하였다. 수술 전 환자의 uPAR 양성률은 34.6\% (9명/26 명)이었다. 26 명의 위암 환자의 수술 전 평균 uPAR농도는 $2980.8 \pm 616.2 \mathrm{pg} / \mathrm{ml}$ 로 대조군과 큰 차이는 없었다 $(\mathrm{p}=0.225)$. 예후인자와의 상관관계를 분석한 결과 연령, 암의 크기 및 위치, 조직학적 아형, 육안적 혹은 조직학적 소견, 림프절 전이, 암의 침윤도와는 통계학적으로 유의성이 없었고 림 프절 전이와 혈관침윤만이 통계학적으로 유의한 차이를 볼 수 있었다 $(\mathrm{p}<0.05)($ Table 2). 또한 수술 전후에 따른 혈청 $\mathrm{uPAR}$ 의 농도를 비교한 결과 4 예를 제외하고는 모두 수술 후 혈청 $\mathrm{uPAR}$ 의 농도가 감소하였고 평균농도는 수술 전 $2980.8 \pm 616.2 \mathrm{pg} / \mathrm{ml}$ 에서 수술 후 $2404.7 \pm 455.9 \mathrm{pg} / \mathrm{ml}$ 로 의

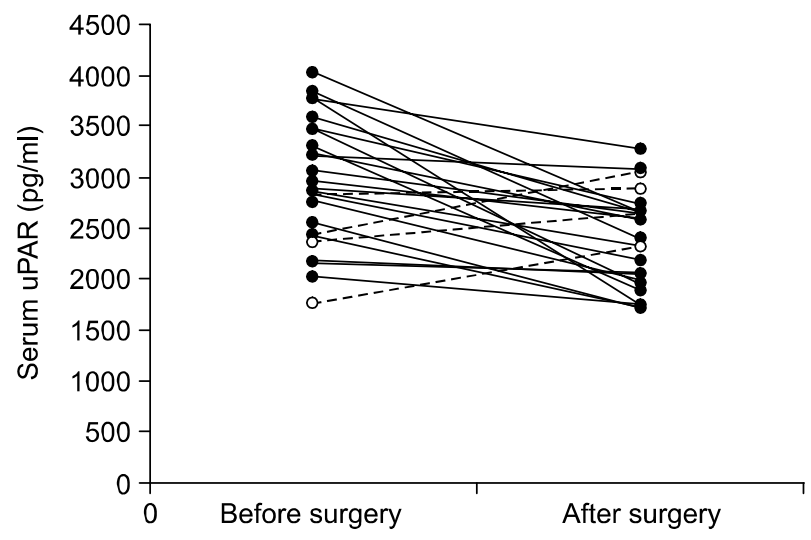

Fig. 3. Serum concentration of $\mathrm{UPAR}$ in 26 patients with stomach cancer before and after surgery. The difference in mean value before $2980.8 \pm 616.2 \mathrm{pg} / \mathrm{ml}$, and after surgery, $2404.7 \pm 455.9 \mathrm{pg} / \mathrm{ml}$ was significant $(\mathrm{p}<0.05)$. 
Hyun A Oh, et al : c-met and UPAR in Gastric Cancer

Table 2. Serum concentration and positive rate of uPAR in patients with stomach cancer

\begin{tabular}{|c|c|c|c|c|c|c|c|c|c|}
\hline \multirow[b]{2}{*}{ Variable } & \multirow{2}{*}{ No } & \multicolumn{2}{|c|}{ Serum uPAR } & \multirow[b]{2}{*}{ p-value* } & \multirow[b]{2}{*}{ Variable } & \multirow{2}{*}{ No } & \multicolumn{2}{|c|}{ Serum uPAR } & \multirow[b]{2}{*}{ p-value } \\
\hline & & $\begin{array}{c}\mathrm{Mean} \pm \mathrm{SD} \\
(\mathrm{pg} / \mathrm{ml})\end{array}$ & $\begin{array}{l}\text { Positive } \\
\text { rate }(\%)^{\dagger}\end{array}$ & & & & $\begin{array}{r}\text { Mean } \pm \text { SD } \\
(\mathrm{pg} / \mathrm{ml})\end{array}$ & $\begin{array}{l}\text { Positive } \\
\text { rate }(\%)^{\mathrm{b}}\end{array}$ & \\
\hline Control & 20 & $2525.4 \pm 366.2$ & $0.0(0 / 20)$ & & Serosa invasion & & & & 0.551 \\
\hline Stomach & 26 & & & & Negative & 23 & $2938.3 \pm 603.9$ & $30.3(7 / 23)$ & \\
\hline Preop & & $2980.8 \pm 616.2$ & $34.6(9 / 26)$ & & Positive & 3 & $3307.1 \pm 744.0$ & $66.7(2 / 3)$ & \\
\hline Postop & & $2404.7 \pm 455.9$ & & & $\mathrm{~L} / \mathrm{N}^{\ddagger}$ metastasis & & & & 0.039 \\
\hline Age & & & & 1.0 & Negative & 16 & $2954.7 \pm 624.9$ & $42.8(3 / 7)$ & \\
\hline$<60$ & 13 & $2937.7 \pm 625.7$ & $30.7(4 / 13)$ & & Positive & 10 & $3022.6 \pm 632.9$ & $66.7(6 / 9)$ & \\
\hline$>60$ & 13 & $3023.9 \pm 628.8$ & $38.5(5 / 13)$ & & Vessel inavasion & & & & 0.018 \\
\hline Sex & & & & 0.415 & Negative & 21 & $2918.1 \pm 549.7$ & $20(4 / 20)$ & \\
\hline Male & 16 & $3041.8 \pm 598.6$ & $43.8(7 / 16)$ & & Positive & 5 & $3244.2 \pm 868.8$ & $83.3(5 / 6)$ & \\
\hline Female & 10 & $2883.3 \pm 663.6$ & $20(2 / 10)$ & & Lymphatic vessel & & & & \\
\hline Size & & & & 0.379 & invasion & & & & 1.0 \\
\hline$<5 \mathrm{~cm}$ & 16 & $2898.5 \pm 586.9$ & $25(4 / 16)$ & & Negative & 12 & $2943.0 \pm 685.7$ & $33.3(4 / 12)$ & \\
\hline$>5 \mathrm{~cm}$ & 10 & $3262.1 \pm 503.7$ & $50(5 / 10)$ & & Positive & 14 & $3013.3 \pm 574.2$ & $35.7(5 / 14)$ & \\
\hline Histologic type & & & & 0.483 & Neural invasion & & & & 1.0 \\
\hline Well & 2 & $2637.0 \pm 855.1$ & $0(0 / 2)$ & & Negative & 13 & $2881.7 \pm 673.4$ & $30.8(4 / 13)$ & \\
\hline Moderate & 8 & $3092.1 \pm 570$ & $50(4 / 8)$ & & Positive & 13 & $3080.0 \pm 562.3$ & $38.5(5 / 13)$ & \\
\hline Poorly & 4 & $3064.4 \pm 969.4$ & $50(2 / 4)$ & & Stage & & & & 0.600 \\
\hline Signet & 10 & $2994.7 \pm 576.6$ & $30(3 / 10)$ & & EGCA & 14 & $2973.9 \pm 617.6$ & $28.6(4 / 14)$ & \\
\hline Undiffrenciated & 2 & $2643.3 \pm 282.0$ & $0(0 / 2)$ & & Stage $\mathrm{Ib}$ & 2 & $2820.6 \pm 926.7$ & $50(1 / 2)$ & \\
\hline Macroscopic type & & & & 0.651 & Stage II & 4 & $2990 \pm 334.3$ & $25(1 / 4)$ & \\
\hline EGCA & 14 & $2973.9 \pm 617.6$ & $28.6(4 / 14)$ & & Stage IIIa & 5 & $2989.7 \pm 890.7$ & $40(2 / 5)$ & \\
\hline Bormann 1,2 & 6 & $3203.7 \pm 556.7$ & $50(3 / 6)$ & & Stage IIIb & 0 & & & \\
\hline Bormann 3,4 & 6 & $2774.2 \pm 697.0$ & $33.3(2 / 6)$ & & Stage IV & 1 & 3317.7 & $100(1 / 1)$ & \\
\hline
\end{tabular}

*Calculated by the chi-square test, ${ }^{\dagger}$ positive serum $\geq 3257.8 \mathrm{pg} / \mathrm{ml},{ }^{\ddagger}$ lymph node

미있게 감소한 것을 관찰할 수 있었다(p=0.012)(Fig. 3).

\section{고 찰}

위암을 비롯한 각종 암은 복합적인 여러 단계의 발암과 정을 거쳐 발생하지만 현재는 유전물질 즉 유전자의 변화 에 의한 것이라는 것이 정설로 받아들여지고 있다. 암에 관 계되는 유전자는 첫째 우성으로 작용하는 암유전자로서 돌 연변이 또는 증폭에 의하여 활성화되어 암을 유발하는 것 이고(13), 둘째는 열성으로 작용하는 항암유전자로 이 유전 자가 소실되거나 유전자의 변화가 있어 작용을 하지 못할 때 암이 유발되는 것으로 항암억제유전자라고도 한다(14). 위암에서 발현되는 암유전자는 c-erbB-2, p53, Rb, 암의 전 이와 관련된 $\mathrm{nm} 23$ 및 암의 증식정도를 나타내는 Ki-67 등이 있으며, 증폭을 나타내는 유전자로는 c-met, K-sam, c-erbB-2 등이 있다.
이들 중에서 c-met 암유전자는 염색체 7번에 위치하고 있 고 증폭의 기전에 의해 활성화되며 c-met 유전자 산물은 강 력한 유사분열 물질로 알려진 hepatocyte growth factor (HGF)의 수용체로 작용한다. $\mathrm{HGF}$ 은 세포의 이동, 증식, 침 습, 신생혈관형성에 관여하고 간세포뿐만 아니라 여러 세 포에서 세포분열 물질로 작용하며 세포독성 작용을 한다고 알려져 있다(15). C-met 유전자 산물은 $190 \mathrm{kD}$ 의 heterodimer로 $50 \mathrm{kD}$ 의 $\mathrm{a}$-chain과 $145 \mathrm{kD}$ 의 $\beta$-chain이 이황화결합 (disulfide bond)에 의해 연결되어 있는데 a-chain과 $\beta$-chain 의 N-terminal 부위는 세포면에 있으며 $\beta$-chain C-terminal 부위는 세포 내에 위치하여 HGF가 c-met에 결합하여 phosphorylation이 일어남으로써 생물학적 반응이 일어난다고 하였다(15). C-met 유전자는 위암 환자에서 활성화된다고 보고되었고(16), c-met의 과발현은 복강 내 전이, 림프절전 이, 장막침범, 림프절 침범과 관련이 있으며 예후와도 관련 이 있다고 한다(11). 


\section{Cancer Research and Treatment 2003;35(1)}

위암조직에서 c-met 유전자의 증폭이 발견되는 빈도는 실험실 및 연구방법에 따라서 다르게 보고된다. Masakazu 등은 128 명의 위암 환자를 대상으로 면역조직화학염색을 시행하여 59명(46.1\%)에서 c-met 양성반응을 보이며 림프절 전이와 관련이 있다고 보고하였고(17), Keizo 등은 102명의 위암환자 중 43 명(42\%)에서 양성반응을 보이며 복강 내 전 이와 관련이 있다고 보고하였다(11). 또한 Kaji 등은 154명 의 위암조직에서 c-met 종양단백의 발현을 분석하여 28 명 $(18 \%)$ 에서 양성반응을 보이고, 병기가 증가할수록 발현율 이 증가하며 MKN-45, TMK-1, MKN-28 세포주 실험을 통하 여 c-met DNA에 대한 antisense oligodeoxyribonucleotide의 사용이 위암의 진행을 억제시킬 수 있다고 하여 치료의 좋 은 목표로 임상적 의의를 보고하였다(18). 본 연구에서도 면역조직화학염색을 통하여 위암 환자에서 c-met 종양단백 의 발현율을 알아보았는데 전체 50예 중 32예(64\%)에서 양 성반응을 보여 앞의 보고보다 높게 나타났다. 이처럼 면역 조직화학염색을 이용한 연구에서 c-met의 양성률이 다양한 이유는 여러 가지가 있겠으나 우선 염색 양성률은 어떤 고 정액을 사용하느냐에 따라서 달라지고 신선 냉동조직인지 파라핀 포매조직인지 또한 사용하는 항체나 염색방법에 따 라서도 양성률이 다를 수도 있고 염색결과의 판정기준이 다양하기 때문이다. 따라서 결과를 해석할 때 위양성에 대 한 상당한 주의가 요망되며 염색 방법과 판정 기준의 표준 화가 선행되어야 할 것이다. Keizo 등은 c-met의 발현이 $30 \%$ 이상일 때 양성으로 판정하였으나 본 연구에서는 암세 포의 염색강도와는 관계없이 세포질, 세포막에 $50 \%$ 이상 염색될 때를 양성으로 판정하였으므로 양성률이 다르게 나 타난 것으로 예상된다. 이처럼 면역조직화학염색을 이용한 암유전자의 발현유무에 관한 연구는 발현정도가 연구마다 다르게 나타나 절대적인 수치로 비교하는 것은 어렵지만, 많은 종류의 단클론 항체가 개발되어 상품화되었고 포르말 린에 고정한 후 파라핀에 포매된 조직에서도 소실된 항원 성을 회복하거나 감수성을 높여 항원성이 약해진 항원을 찾아내는 염색법의 개발로 인해 진단 및 연구분야에서 분 자생물학적 기법과 함께 활발히 사용되고 있다(19).

간세포 성장인자는 운동성 및 분열성 활성능력을 가지는 사이토카인으로 그 수용체인 c-met과 결합함으로써 암의 침투, 증식, 이동, 전이, 혈관형성 등의 많은 생물학적 과정 에 관여한다고 보고되고 있는데(20) 그러나 어떠한 기전으 로 암세포 진행과 전이에 관계되는 지는 명백하지 않지만, 활성화된 c-met이 과표현된 신장 상피세포 연구에서 기저 막 용해에 중추적 역할을 하는 serine protease의 일종인 uPA 유전인자의 표현이 증가됨을 보여(21) uPA가 c-met의 활성 으로부터 암의 침윤에 관계가 있다고 하였다. $\mathrm{uPA}$ 는 비활
성 형태의 plasminogen으로 부터 활성화된 단백분해효소인 plasmin을 생성시키므로 기저막과 기질을 구성하는 peptide 결합을 비가역적으로 파괴시키는데 중추적 역할을 할 것으 로 생각되며 $\mathrm{uPAR}$ 는 $\mathrm{uPA}$ 의 활성화에 반드시 필요하므로 $\mathrm{uPAR}$ 는 세포의 단백 분해과정의 속도조절요소라 할 수 있 겠다. uPAR는 분자량이 $55,000 \sim 60,000 \mathrm{Da}$ 의 glycoprotein으 로 glycosyl phosphatidylinositol (GPI)에 의하여 세포외 표면 에 고정되어 있으며 암세포의 침윤에 중요한 역할을 하는 $\mathrm{uPA}$ 의 활성화에 필수적이므로 $\mathrm{uPAR}$ 또한 암세포의 침윤 과 깊은 관련이 있을 것이며 다음과 같은 결과(22)는 uPAR 가 암세포의 전이와 침윤에 중요한 역할을 한다는 것을 시 사한다. 첫째는 uPA와 uPAR을 같이 표현하는 LB6 mouse만 이 chick embryo의 융모막에 효과적으로 침윤하며, 둘째는 human glioblastoma세포에 의한 in vitro 침윤은 anti-uPAR항 체로 $\mathrm{uPA}$ 가 수용체에 결합하는 것을 방해함으로 억제되고, 셋째는 human melanoma 세포가 uPA를 분비하여도 수용체 에 결합되지 않고는 세포침윤에 $\mathrm{uPA}$ 를 효과적으로 이용하 지 못한다는 점이다.

$\mathrm{uPA}, \mathrm{uPAR}$ 의 암 예후인자로서의 가능성은 위암, 유방암 등에서 보고되었고 Keizo 등은 위암 환자의 조직에서 면역 조직화학 염색을 통하여 발현유무를 조사하여 암의 침윤뿐 만 아니라 예후와 관련이 있다고 보고하였다(11). 우리나라 에서는 2000년 공 등이 268명의 유방암 환자의 조직에서 ELISA방법을 이용하여 uPAR를 측정하여 조직의 uPAR의 발현정도가 $\mathrm{TNM}$ 병기와 관련이 있으며 특히 $\mathrm{T} 1$ 병기에서 가장 높게 측정되고 초기암의 침윤에 중요한 인자로 작용 한다고 보고하였다(23). 라 등은 유방암 환자의 혈액과 조 직에서 $\mathrm{uPA}, \mathrm{uPAR}$ 를 측정하여 혈액에서 관찰되는 $\mathrm{uPA}$, $\mathrm{uPAR}$ 은 조직 내의 발현소견을 대변할 수 있다고 하였다 (24). 즉, 혈청 내 uPAR치는 uPAR에 의해 매개되는 세포면 단백 분해의 활성정도를 반영하므로, 본 연구에서는 위암 환자의 혈청에서 uPAR를 측정하여 대조군과 비교하고 수 술전후에 어떠한 변화가 있으며 예후인자와는 어떠한 관계 가 있는지 조사하였다. 총 26명의 위암환자를 대조군과 비 교하였을 때 큰 차이를 볼 수 없었는데 이것은 대부분 $\mathrm{uPAR}$ 는 침윤과 전이에 관계하는데 비해 대상에 포함된 환 자가 대부분 조기위암환자였기 때문으로 생각한다. 수술 전후 $\mathrm{uPAR}$ 농도를 비교한 결과 4 예를 제외하고는 평균농도 가 수술 전 $2980.8 \pm 616.2 \mathrm{pg} / \mathrm{ml}$ 에서 수술 후는 $2404.7 \pm 455.9$ $\mathrm{pg} / \mathrm{ml}$ 로 의미 있게 감소한 것을 볼 수 있었다 $(\mathrm{p}<0.05)$. 위암 환자에서 $\mathrm{uPAR}$ 와 예후인자의 상관관계를 살펴보면 복강내 전이, 장막침윤, 혈관침윤 등과 관계가 있으며, 세포외 기질 을 파괴하는 특성 때문에 특히 원격전이 보다는 국소적 침 범과 상관관계가 더 있다고 보고되고 있다(11). 본 연구에 
서는 혈관침윤과 림프절 전이와는 상관관계가 있었으나 $(\mathrm{p}<0.05)$ 다른 예후인자와의 관련성은 증명할 수 없었다. c-met, uPAR 과발현이 다른 많은 보고들과 같이 불량한 예후와 연관이 있고 HGF/c-met 신호체계로 인한 uPA-uPAR 계의 활성이 암의 전이에 관계있다는 보고에 근거하여 향 후 c-met 발현과 uPAR의 연관성을 확인하여 현재까지 진행 성 위암인 경우 뚜렷하게 효과가 있는 항암화학요법 치료가 없으며 또한 부작용이 많아 적극적 치료로 이용하고 있지 않는 상황에서 암진행에 중요한 역할을 하는 인자를 규명하 여 치료목표로서 임상적 적용의 기초자료로 쓰고자 한다.

\section{결 론}

암의 침윤과 전이에 관련이 있다고 보고되는 c-met과 $\mathrm{uPAR}$ 를 위암 환자의 조직과 혈청에서 각각 측정한 결과 조 직에서 c-met의 과발현은 환자의 병기가 증가할수록 높은 발현을 보였고, 혈청 $\mathrm{uPAR}$ 치는 암의 혈관침윤과 림프절 전 이와 관련이 있으며 수술 후에 의미있게 감소하였다. 따라 서 c-met의 과발현 시 수술 후 보다 적극적인 치료를 시행하 고, 침윤정도와 관련이 있는 혈청 uPAR치를 수술 전 측정 하여 상승 시에 uPAR 억제약물을 사용함으로써 환자의 치 료효과를 증가시킬 수 있으리라 기대된다.

\section{REFERENCES}

1. Noh SH, Yoo CH, Lee HY, Kim HG, Oh YH, Min JS. Prognostic significancer of p53, c-erbB-2, nm23 and Ki-67 expression in patients with advanced gastric carcinoma. J Korean Cancer Assoc 1999;31:699-709.

2. Yonemura Y, Ninomiya I, Yamaguchi A, Fushida S, Kimura $\mathrm{H}$. Evaluation of immunoreactivity for c-erbB-2 protein a marker of poor short term prognosis in gastric cancer. Cancer Res 1991;51:1034-1038.

3. Huebner RM, Todaro GJ. Oncogenes or RNA tumor viruses as determinants of cancer. Proc Natl Acad Sci USA 1969;64: 1087-1094.

4. Nakasato F, Sakamoto H, Mori M, Hayashi K. Amplification of the c-myc gene amplification in human stomach cancers. Gann 1984;75:737-742.

5. Kodo T, Matsushima S, Sasaki A, Danjo Y, Kakinuma M. Cmyc gene amplification in primry stomach cancer. Jpn J Cancer Res 1985;76:551-554.

6. Bottaro DP, Rubin JS, Faletto DL, Chan AM, Kmiecik TE, Vande Woude GF, Aaronson SA. Identification of hepatocyte growth factor receptor as the c-met proto-oncogene product. Science (Washington DC) 1991;251:802-804.

7. Rubin JS, Bottaro DP, Aaronson SA. Hepatocyte growth factor/scatter factor and its receptor, the c-met proto-oncogene product. Biochim Biophys Acta 1993;1155:357-371.

8. Jeffers M, Rong S, Vande Woude GF. Hepatocyte growth factor/scatter factor-Met signaling in tumorigenicity and inva- sion/metastasis. J Mol Med 1996;74:505-513.

9. Park M, Dean M, Cooper CS, Schmidt M, O'Brien SJ, Blair DJ. Mechanism of met oncogene activation. Cell 1986;45: 895-904.

10. Ueki T, Fujimoto J, Suzuki T, Yamamoto H, Okamoto E. Expression of hepatocyte growth factor and its receptor c-met proto-oncogene in hepatocellular carcinoma. Hepatology 1997; 25:862-866.

11. Keizo T, Yakata Y, Naomi N, Yasuo H, Sachio F, Takashi $\mathrm{F}$, Koichi $\mathrm{H}$, et al. The relation bet-ween the growth patterns of gastric carcinoma and the expression of hepatocyte growth factor receptor (c-met) autocrine motility factor receptor (AMFR), and urokinase type plasminogen activator receptor (UPAR). Cancer 1998;82:2112-2122.

12. Pepper MS, Matsumoto K, Nakamura T, Orci L, Montesano R. Hepatocyte grwoth factor increase urokinase-type plasminogen activator (u-PA) and urokinase-type plasminogen activator receptor (u-PAR) expression in Madin-Darby canine kidney epithelial cells. J Biol Chem 1992;267:20493-20496.

13. Klein G, Klein E. Evolution of tumors and the impact of molecular oncology. Nature 1985;315:190-195.

14. Knudson AG Jr. Hereditary cancer, oncogenes, and antioncogenes. Cancer Res 1985;45:1437-1443.

15. Weidner KM, Hartmann G, Sachs M, Birchmoier W. Properties and functions of scatter factor/HGF and its receptor c-Met. Am J Respir Cell Mol Biol 1993;8:229-237.

16. Yonemura Y, Kaji M, Hirono Y, Fushida S, Tugawa K, Fujimura $\mathrm{T}$, et al. Correlation between overexpression of c-met gene and the progression of gastric cancer. Int J Oncol 1996; 8:555-560.

17. Masakazu N, Hidetow S, Yukishige Y, Akihiko W, Mitsutoshi T, Jun Y, Masahiko M. Prognostic significance of amplication and overexpression of c-met and c-erbB-2 in human gastric carcinoma. Cancer 1999;85:1892-1902.

18. Kaji M, Yonemura Y, Harada S, Liu X, Terada I, Yamamoto $\mathrm{H}$. Participation of c-met in the progression of human gastric cancers: anti-c-met oligonucleotides inhibit proliferation of invasiv-ness of gastric cancer cells. 1996;3:393-404.

19. Fan AG, Nakane PK. Immunohistochemistry with emzyme labeled antibodies. J Immunol Meth 1981;47:129-134.

20. Rong S, Segal S, Anver M, Resau JH, Vande Woude GF. Invasiveness and metastasis of NIH 3 T3 cells. Induced by met-hepatocyte growth factor autocrine stimulation. Proc Natl Acad Sci 1994;91:4731-4735.

21. Besser D, Bardelli A, Didichenoko S, Thelen M, Comoglio PM, Ponsetto C, Regamine Y. Regulation of the uokinase-type plasminogen activator gene by the oncogene tcr-met GRB2. Oncogene 1997;14:705-711.

22. Park HW, Kook YH, Choi SB, Cha CY. Localization of urokinase type plasminogen activator receptor on tumor cells by immunohistochemistry. J Korean Cancer Assoc 1996;28:159167.

23. Gong SJ, Rha SY, Chung HC, Park JO, Yoo NC, Roh JK,Yang WI, Lee KS, Min JS, Kim BS, Chung HC. Clinical significancer of urokinase-type plasminogen activator receptor (uPAR) expre-ssion in breast cancer tissues. J Korean Cancer Assoc 2000;32:53-59.

24. Rha SY, Park JO, Gong SJ, Park SH, Yoo NC, Yang WI, Roh JK, Min JS, Lee KS, Kim BS, Chung HC. Clinical relevancer of urokinase-type plasminogen activator (uPA), uPA receptor, plasminogen activator inhibitor-1 co-expression from tissue and serum of breast cancer as targets of biotherapy. J Korean Cancer Assoc 1999;31:256-266. 